\title{
Identity Processes to Trigger Turnaround in Response to Organizational Decline
}

\author{
Sam Rockwell ${ }^{1}$ \\ ${ }^{1}$ Downing St, Thornton, USA \\ Correspondence: Sam Rockwell, 13279 Downing St, Thornton, CO 80241, USA. Tel: 1-303-252-0189. E-mail: \\ srockwellpubs2015@gmail.com
}

Received: November 19, 2015

Accepted: February 14, 2016 Online Published: February 25, 2016

doi:10.5539/ijbm.v11n3p11

URL: http://dx.doi.org/10.5539/ijbm.v11n3p11

\begin{abstract}
This article proposes a model of identity-related social processes that, when applied during organizational decline, is hypothesized to support turnaround and avoid organizational death. The social processes are retiring, reclaiming, reaffirming, regenerating, and reimagining identity attributes. Although this model is rooted in past studies and literature on organizational decline and organizational identity, empirical research is needed to validate or adjust the model. Future work could involve examination of identity negotiations within past cases of organizational decline and turnaround as well as devising and testing specific retiring, reclaiming, reaffirming, regenerating, and reimagining interventions.
\end{abstract}

Keywords: organization turnaround, organizational decline, organizational identity, social processes

\section{Introduction}

Organizational decline is a natural part of an organization's lifecycle, despite biases in literature and practice that unfettered, constant growth is the natural state of organizations (Bedeian, 1980; Penrose, 1959; Torres, Serra, Ferreira, \& Menezes, 2011). However, what happens during decline is that insiders and outsiders tend to enact self-fulfilling prophecies about the organization that act to accelerate and assure organizational decline and death (Edwards, McKinley, \& Moon, 2002). Moreover, few recommendations have been made for organizations to avoid this fate.

This article examines the social processes organization members engage in related to organizational identity during times of organizational decline and offers a model of the social processes that may spark organizational turnaround. Those processes are reclaiming, reaffirming, regenerating, and reimagining.

\section{Organizational Decline}

Three decades ago, Whetten (1980a) argued that organizational decline was a neglected topic in management studies, noting that "although [it is] of important and fundamental concern to organizations, [it] has been given little attention by research" (p. 577). This gap in research remains unfilled (Serra, Ferreira, \& Ribeiro de Almeida, 2013), as the majority of business and management studies are biased towards success and successful organizations, while business failure and decline is less examined. Extant research on decline, thus, is rather limited (Torres et al., 2011). In fact, although some scholars such as Barnard (1938) stated that firms' main measure of success is their ability to survive, most authors still take growth as the normal condition for an organization (Torres et al., 2011).

Despite the bias in business and management research that growth is the normal state of organizations (Bedeian, 1980; Penrose, 1959), other research acknowledges that organizations evolve through a lifecycle that requires from them the ability to adapt and renew to survive (Scott, 1971). Usually, the lifecycle models have four stages: birth, growth, maturity, and decline. Sometimes, these also include a renewal or turnaround stage (Adizes, 1979; Hoy, 2006; Kimberly \& Miles, 1980; Pandit, 2000; Quinn \& Cameron, 1983). Organizations that fail to respond appropriately to decline may end up in complete failure.

Although statistics and research are available on decline and failure in small companies (wherein decline and failure typically are attributed to the liability of newness and a lack of several types of physical, technological, financial and social resources), the reality is that well-known and reputable corporations as well as small entrepreneurial firms face organizational decline and failure. Nevertheless, this topic remains under-examined. In 
Serra et al.'s (2013) examination of extant literature, they found that of the 18 journals considered, a total of 31,218 articles were published - and only $104(0.33 \%)$ of which discussed organizational decline. Moreover, attention to the topic appeared to largely stop in the 1990s (Torres et al., 2011).

\subsection{Definition}

Sheppard (1994) provided a broad definition of organizational death, meaning a situation where the organization can no longer perform its functions and, therefore, ceases to exist. In contrast, organizational decline has been defined as stagnation or cutback (Whetten, 1980b), a decrease in the number of organizational employees (Ford, 1980), maladaptation to the environment (Weitzel \& Jonsson, 1989), a downturn in organizational size or performance (McKinley, 1987), and a decrease in an organization's resource base (Cameron, Kim, \& Whetten, 1987). In later research, theorists converged on decline as decrease in an organization's resource base (Edwards et al., 2002). These definitions are helpful in that they distinguish decline from related constructs like organizational downsizing, organizational restructuring, and layoffs, which largely focus on adjusting staffing (Freeman \& Cameron, 1993; McKinley \& Scherer, 2000).

This article utilizes the definition of organizational decline offered by Cameron et al. (1987) and Freeman and Cameron (1993) that organizational decline involves an involuntary, steady, and substantive decrease in the organization's resource base over at least two years (Robbins \& Pearce, 1992). Thus, decline is distinguished from turbulence (rapid and discontinuous fluctuations in revenues or resources; Cameron et al., 1987), organizational downsizing (intentional adjustments to staffing; Freeman \& Cameron, 1993); organizational crises (high-impact events that threaten survival and require immediate action; Pearson \& Clair, 1998); organizational jolts (environmental upsets that do not necessarily erode the organization's resource base; Meyer, 1982); and organizational stagnation (long-term low performance rather than steady depletion of organizational resources; Masuch, 1985).

Organizational decline begins as an often imperceptible shift toward organizational death (Heine \& Rindfleisch, 2013). Importantly, decline begins several years before visible signs of failure actually emerge (Hambrick \& D'Aveni, 1988). Even when the initial signs of decline surface, managers often ignore or hide decline or, at best, fail to effectively respond to it. The next section more deeply examines the believed causes of organizational decline.

\subsection{Causes}

Given that organizational decline, if unchecked, leads to ultimate failure and organizational death, researchers have sought to understand the causes of decline. Although some researchers purport that decline occurs primarily in the absence of performance or when failing to observe success factors, Heine and Rindfleisch (2013) point out that "the interplay of variables promoting organizational performance can be different from the interplay of variables resulting in organizational decline" (p. 11); thus necessitating a separate theory of organizational decline.

\subsubsection{Environmental Conditions}

One stream of research indicates that organizational decline is associated with macro-environmental factors such as global competition, shrinking customer bases in a product market, and deregulation, among others (Porter, 1980; Pfeffer \& Salancik, 1978). Attempts at understanding these dynamics have involved applying biological and ecological frameworks to the concept of organizational lifecycles. For example, Hannan and colleagues (e.g., Freeman \& Hannan, 1983; Hannan \& Carroll, 1992) used these frameworks to make predictions about mortality rates of generalist and specialist organizations in various types of environments based on their population density and other dynamics. For example, the concept of resource partitioning, when applied to organizational lifecycles, predicts that a high concentration of generalist organizations in the mass market is associated with higher mortality of generalists and lower mortality of specialists.

\subsubsection{Organizational Conditions}

Another large stream of research has examined the organizational conditions and states of being associated with decline, such as decline resulting from the reduction of organization dimension or a lack of internal efficiency (McKinley, 1987). Several researchers, in particular, have examined decline as a consequence of a liability of newness, which implies that newer organizations have not had enough run time to establish their routines and capabilities to weather the turbulence endemic to operating (Baum \& Shipilov, 2006). It follows that as they experiment with various strategies, approaches, and structures, they might attempt something that leads to the organization's demise. Moreover, lacking established relationships with suppliers, customers, and other stakeholders, newer organizations have less access to resources, less power as social actors, and less solidified 
roles in their environment, all of which place them at a disadvantage for winning business, creating needed strategic alliances, and ultimately surviving. Hannan and Freeman (1984) added that newer organizations also have not had the time to establish a record of accountability and reliability; thus, they do not fare as well when competing for business.

Organizational decline also has been associated with a liability of smallness (Aldrich \& Auster, 1986; Venkataraman \& Low, 1994). Smaller organizations generally have access to fewer resources, less capital and less ability raise capital, less leverage to secure desired talent and ability to develop it, and fewer sources of competitive advantage in the marketplace. All of these place small organizations at greater risk for decline.

Yet another organizational condition that has been associated with organizational decline is the failure to acquire, preserve, or leverage critical resources and assets associated with creating and sustaining the organization's competitive advantage (Acedo, Barroso, \& Galan, 2006; Conner, 1991; Barney, 2001; Kraaijenbrink et al., 2010). According to Barney (2001), these resources and assets - in order to create competitive advantage - must be (a) valuable for capitalizing on opportunities or diminishing threats, (b) rare compared to competitors' resources and assets, (c) resistant to imitation by competitors, and (d) non-substitutable.

\subsubsection{Failure to Adapt}

A third stream of research on organizational decline points out that stagnation or an organization's failure to properly respond to changes in the industry or environment can lead to missteps and decline (e.g., Staw, Sandelands, \& Dutton, 1981; Weitzel \& Jonsson, 1989; Whetten, 1980b). This is consistent with contingency theory, which holds that changes in the variables surrounding an organization (e.g., its environment) requires adaptation by the organization if that organization is to survive (Donaldson, 2001).

For example, organizations that struggle to keep pace with the rapid technological innovations that have been occurring in recent decades can quickly find themselves at an increasing disadvantage compared to competitors (Hambrick \& D'Aveni, 1988). If they fail to incorporate and adapt to these changes, they may soon find themselves in decline, as did the Polaroid Corporation in the 1990s, when it struggled to shift from analog to digital imaging (Tripsas \& Gavetti, 2000).

Researchers have examined four common reasons why organizations fail to adapt: the liability of success, escalating commitment, rigidity and self-reinforcing cycles, and lack of exploration and innovation. At an organization's inception, the focus is on developing a core set of resources, features, and deliverables that help the organization deal with recurring challenges and create competitive advantage (Becker, 2008). As these capabilities become increasingly honed, stability and reliability emerges, further reinforcing the organization's success. However, successful organizations face a danger themselves that has been dubbed the Icarus paradox (Miller, 1990), wherein a dynamic of 'success breeding failure' begins to take hold (Whetten, 1980b). In such cases, success can create overconfidence, self-assurance, and a reluctance to adapt that turns into deadly inflexibility (Heine \& Rindfleisch, 2013). Moreover, managerial overconfidence tends to be heighten in cases of threat (Argenti, 1976).

A liability of success subsequently occurs because singular focus on past successful strategies and routines can cultivate a uniformity of resources, competencies, and perspectives within the organization that preclude its ability to develop alternate solutions and to detect and respond to shifts in the market or other environmental conditions (Barnett \& Pontikes, 2008; Lumpkin \& Dess, 2006; Miller, 1993).

Inflexibility and failure to adapt also can occur as the result of escalating commitment, defined as increasing emotional, financial, and social investment in a losing course of action (Bowen, 1987; Brockner, 1992). Accompanying this over-commitment is self-justification that consciously and subconsciously prompts decision makers distort and ignore negative feedback and resist or organizational adaptations until decline, failure, and even organizational death is unavoidable (Heine \& Rindfleisch, 2013).

Failure to adapt also has been extensively examined in terms of the creation of self-reinforcing feedback loops and patterns of decision making that culminate in downward spirals leading to decline (Carmeli \& Schaubroeck, 2006; Hambrick \& D’Aveni, 1988; Hayward \& Shimizu, 2006; Tversky \& Kahneman, 1981).

These concepts are consistent with path dependence theory, which suggest that the organization's history of resolving problems and configuring its resources, competencies, and routines can create a sort of organizational lock-in (Pierson, 2000) that precludes trajectories available earlier and obstructs alternate ways of interpreting and responding to its environment. This concept also is related to organizational imprinting theory, which posits that founders' early actions and the organization's founding conditions have a lasting impact on corporate structures, strategies, and routines (Johnson, 2007). Arthur (1994) added that four particular triggers increase the 
likelihood of organizational lock-in: large, sunk setup or fixed costs; depth of learning and experience; coordination effects stemming from network externalities; and adaptive expectations. It follows that the clues to the organization's decline may be found in the idiosyncratic history of an organization and decades-old patterns of decision making rather than in the organization's recent financial records.

Not only does lock-in hamper or obstruct the organization from effectively responding to new environmental conditions (Baum \& Shipilov, 2006); but also, the organization's inflexibility creates opportunities for competitors to enter and undermine the organization's competitive position (Tushman \& Anderson, 1986).

A fourth reason for failure to adapt is lack of organizational variety and a lack of exploration and innovation (McKinley, 1993). Heine and Rindfleisch (2013) explained that having too little variety hampers the organization from experimenting with new types of resources, locating additional profitable avenues for operating, and creating new forms of competitive advantage. Lack of exploration and innovation can result from poor clarity, accountability, and incentives surrounding these tasks (Stieglitz \& Heine, 2007), as well as overemphasis on maintaining or optimizing status quo (Brown \& Starkey, 2000; Gavetti \& Levinthal, 2000; Kahneman, Knetsch, \& Thaler, 1991; Tripsas \& Gavetti, 2000) and conscious or subconcious resistance to new information and alternatives (Hodgkinson \& Wright, 2002).

\subsubsection{Self-Fulfilling Predictions of Decline}

Organizational decline also has been researched as the consequence of subconscious self-fulfilling prophecies of failure that predict and precipitate decline, even in cases where the prediction was inaccurate (Edwards et al., 2002). Edwards et al. (2002) illustrated this phenomenon in his presentation of cases of organizational decline - one which was unintentionally precipitated as a result of managerial predictions and one which was unintentionally enacted through the predictions and subsequent behaviors of external stakeholders including customers, credit rating agencies, suppliers, and banks.

Edwards et al. (2002) elaborated that predicting and trying to adjust to expectations of an organization's decline actually accelerate the decline. Typical (and typically unhelpful) managerial reactions to predictions to decline include disinvestments such as freezes on hiring and infrastructure development or budgetary and staffing cuts. These decisions can undermine organizational capabilities, thereby creating disadvantages and possible decline (Wernerfelt, 1984). Typical stakeholder reactions to predictions of decline include tightening payment deadlines, reducing credit lines, or restricting business. Although these measures can protect the stakeholders' interests, these same measures can spell disaster for the organization, which may rapidly find itself in a crisis of steady decline.

Edwards et al. (2002) pointed out that in these ways, predicted decline quickly becomes an inevitable and constructed decline, further confirming the stakeholder's prediction and bringing the decline into fruition (McKinley \& Scherer, 2000). Moreover, once one internal or external constituent predicts and begins enacting an organization's decline, a contagion effect occurs wherein enactment of the decline becomes a group phenomenon, thus assuring the eventual demise of the organization.

\subsection{Outcomes}

Decline is considered a normal part of the organizational lifecycle. Research has diverged regarding the path ahead for an organization that experiences decline (McKinley, 1993). One body of research suggests that organizational decline triggers adaptation and innovation, while the other body of research argues that inhibited adaptation and innovation is the only fate for a declining organization (Audia \& Greve, 2006; McKinley, Latham, \& Braun, 2014). As Edwards et al. (2002) pointed out, well-intentioned managerial responses to decline, such as increased focus on efficiency, accountability, and cost controls, may act only to deepen the decline. Moreover, these activities serve to increase rigidity (thereby hampering adaptation) and restrict innovation (Staw et al., 1981), which were noted as further precipitating decline (Carmeli \& Schaubroeck, 2006; Hayward \& Shimizu, 2006; Heine \& Rindfleisch, 2013; Tripsas \& Gavetti, 2000). At the same time, Staw et al. (1981) has proposed that under some conditions, turnaround may actually be achieved through rigidity and risk avoidance.

It follows that organizational decline does not necessitate the ultimate stagnation or death of the organization (Miller \& Friesen, 1984). Although turnaround following decline is not guaranteed, it is possible, depending upon the efforts of organization members. The present article examines the social processes organization members engage in related to organizational identity in the midst of decline and how these relate to organizational turnaround or mortality.

\section{Organizational Identity}

A vast body of research has been produced on organizational identity (Corley et al., 2006; Elstak, 2008; Ravasi 
\& Schultz, 2006; Van Rekom, Corley, \& Ravasi, 2008; Whetten, 2006). Organizational identity is traditionally defined as who we are, consisting of identity claims that reflect the organization's central, distinctive, and enduring characteristics (Whetten, 2006). Importantly, to qualify as an identity claim, the claim has to meet all three criteria - namely, that it is central, distinctive, and enduring regarding the organization. However, different stakeholders perceive and conceive of the same organization differently. It follows that organizations may be viewed as having multiple identities, depending on the perspective taken (Harrison, 2000; Pratt \& Foreman, 2000).

Dutton, Dukerich, and Harquail (1994) distinguished between the constructs of collective identity, perceived organizational identity, organizational reputation, and construed external image. Gioia and Thomas (1996) clarified that identity refers to internal stakeholders' perceptions, whereas reputation and image refer to outsiders perceptions. Czarniawska (1994) asserted that organizational narratives and autobiographies constitute organizational identity claims. Later researchers proposed several constructs, all closely related to identity, to allow for the inclusion of diverse perceptions and points of view (Whetten \& Godfrey, 1998).

\subsection{Impacts and Outcomes of Organizational Identity}

A positive and distinctive organizational identity attracts the recognition, support, and loyalty of organizational members, key stakeholders, and constituents (Ashforth \& Mael, 1989). Therefore, organizational identity can be considered a key form of self-preservation (Czarniawska, 1997). Moreover, how external constituents view the organization's identity can affect their ability to access needed human and material resources for their survival (Pfeffer \& Salancik, 1978).

Threats to an agreed-on identity characteristic will strongly influence an organization's performance because its very performance depends on internal and external perceptions of its legitimacy (Suchman, 1995), which in turn affects its ability to access needed resources (Pfeffer \& Salancik, 1978). Thus, organizations have a strategic interest in establishing and maintaining an identity destined to be positive in relation to institutionalized consensus.

\subsection{Emergence of Organizational Identity}

Cornelissen (2006) offered a typology of organizational identity perspectives, highlighting three paradigms that explain how identity emerges. These include the social actor paradigm, which suggests that an organization's identity reflects its material characteristics; the social constructionist paradigm, which suggests that identity acts as a tool of cognitive framing; and the linguistic-discursive paradigm, which posits that identity is the result of a continuously narrated argument.

The social actor paradigm conceptualizes identity as an objective property of the organizational entity (Cornelissen, 2006) and indicates what is central, distinctive, and continuous (Scott, 2003; Whetten \& Mackey, 2002). Key to this paradigm is the set of messages (identity claims) communicated by organizational leadership and management, as these shape organizational members' conceptions of what is central, enduring, and distinctive to the organization (Ravasi \& Schultz, 2006). Moreover, this paradigm assumes that leaders' statements about the identity are accurate and that they indeed describe fixed features of the organization (Chreim, 2005).

According to the social constructionist paradigm (Cornelissen, 2006), identity is created and sustained through the sensemaking interactions and interpretations of organization members and stakeholders. Collectively, these shared understandings form broad agreements about who the organization is and what qualities are core, distinctive, and enduring (Alvesson \& Empson, 2004; Ravasi \& Schultz, 2006; Scott \& Lane, 2000). These understandings become self-reinforcing because they continue to shape successive perceptions, behaviors, and experiences. Ran and Duimering (2007) elaborated that the social construction of identity reflects a complexity of organizational discourse, infused with many texts, and authored by numerous stakeholders over time. In this way, identity characteristics are decided through the negotiation, claims, and counterclaims of a diversity of organizational stakeholders, ultimately culminating in consensus around a particular version of an organization's identity (Berger \& Luckmann, 1966). Ran and Duimering (2007) added that socially constructed identity claims have four characteristics: they are (a) intentional, in that they define the organization in ways aligned with certain political and strategic purposes; (b) temporal, in that they fit the organization for a certain period in time; (c) relational, in that they are driven by and related to all the other factors influencing the organization's existence; and (d) externally directed to communicate an image to external stakeholders for the purpose of influencing events and decisions.

The linguistic-discursive paradigm concerns how language constructs what the reality of the organization is for 
members (Chreim, 2005; Cornelissen, 2006). Central to the act of linguistically constructing the organization identity is the use of tools such as metaphors (Cornelissen 2006; Heracleous \& Jacobs 2008), storytelling (Czarniawska-Joerges, 1997; Humphreys \& Brown, 2002), categorizations (e.g., Ran \& Duimering, 2007), labels and names (e.g., Martin, 2002), and power and political plays (Chreim 2005; Sheep \& Hollinsbe 2009). Moreover, this process is one of ongoing narration, involving creating, adjusting, affirming, and rejecting various interpretations (Czarniawska-Joerges, 1997).

Harquail and King (2010) noted that the emergence of organizational identity, across many paradigms, presume a heavily reliance on linguistic activities. They challenged this assumption, arguing that focusing narrowly on cognitive and language-based constructions or representations of identity ignore far more of members' comprehension of their firms than it includes. They countered that an embodied cognitive perspective for understanding organization identity was needed, explaining that organization members develop understanding of their organizations and its various attributes by processing information and gaining knowledge about the organization through their bodily experiences in and of the organization.

Together, these paradigms provide insights that, if integrated, reveal the multifaceted way that organization identity is discovered or created, understood, and propagated across members. Hatch and Schultz (2008) further argued that organizational identity is dynamic, in that stakeholders constantly reassess and reconstruct the characteristics of an organization. This begs the question of what happens when an organization is in decline and, specific to this article, how identity (and the social processes implicated in generating identity) might be harnessed to avoid accelerating decline and instead support turnaround.

\subsection{Social Processes Surrounding Identity during Organizational Decline}

Rather than enduring for long periods of time, identities tend to adapt quickly in accordance with environmental changes (Gioia, Schultz, \& Corley, 2000; Gioia \& Thomas, 1996). Consistent with the social actor view, managers' conceptions of what is central, enduring, and distinctive may shift (along with their identity claims) based on revised understandings of the organization and its environment. According to a social constructionist view, internal and external changes (especially those that threaten an organization's identity) require organizational members to engage in additional sensemaking about the organization and to update their conceptions of its identity. Dutton and Dukerich's (1991) discussion of external changes affecting the Port Authority showed how employees' perceptions of their organization's identity were challenged, leading them to reconsider and revise their ideas.

Ran and Duimering (2007) examined the construction of identity through identity claims during a time of organizational identity threat. They studied how stakeholders use language to construct identity in accordance with their own interests. They elaborated that the identity claims members make serve to (a) create a unique set of value-laden categories; (b) position the organization within these categories (whether positively or negatively); (c) project images of how the organization's identity may shift and transform; (d) articulate the organization's past, present, and future identities; and (e) indicate how the organization acts and interacts with other individuals or organizations. Consistent with the linguistic-discursive paradigm, members' language and sensemaking occurs in an ongoing manner (Czarniawska-Joerges, 1997); therefore, discourses about the organization naturally shift in concert with shifts occurring internal and external to the organization (Chreim, 2005; Cornelissen, 2006; Couple \& Brown, 2004). In a similar way, organization members' bodily experiences in and of the organization can change in the midst of identity threats, yielding different embodied cognitions of and subsequent identity claims related to the organization (Harquail \& King, 2010). The resulting identity claims, whether seen through a social actor, social constructionist, linguistic, or embodied cognition lens, can exacerbate and accelerate decline or, in contrast, support the organization's turnaround (Edwards et al., 2002).

For example, the processes of sensemaking and sensegiving about the organization during times of identity threat and organizational change creates expectations for the present and future, yielding self-fulfilling prophecies that members are consciously and subconsciously enacting as reality (Edwards et al., 2002). Starbuck, Greve, and Hedburg (1978), for example, provided the case of a Swedish organization that projected it would be unable to secure any sales outside Sweden. It then enacted this reality by exerting no effort to make sales outside the country. It is critical to raise conscious awareness of these self-fulfilling prophecies and to realize that alternate possibilities are also within reach. The next section presents a model of identity-related social processes and how these may be leveraged to support organizational turnaround.

\section{A Model of Identity-Related Social Processes during Decline}

When organizations are in a state of decline, chaos can take over as leaders and employees members witness the organization go into a downward spiral and efforts give way to desperation and even chaos. Given that identities 
often adapt quickly to meet environmental changes (Gioia, Schultz, \& Corley, 2000; Gioia \& Thomas, 1996), the organization can quickly lose sight of what and who it is in the midst of the associated turbulence.

Recovering the organization and avoiding the self-fulfilling prophecy of decline requires concerted attention to the organization's identity. Sveningsson and Alvesson (2003) defined identity work as "people being engaged in forming, repairing, maintaining, strengthening or revising the constructions that are productive of a sense of coherence and distinctiveness" (p. 1165). Consistent with Schultz, Maguire, Langley, and Tsoukas (2012), the proposed model asserts that this identity work is an ongoing process and that the very process of identity work is itself a basic form or characteristic of the organization.

Furthermore, as Kreiner, Hollensbe, Sheep, Smith, and Kataria (2015) have observed, identity work requires members to renegotiate how they view their organization's identity - namely, organization identity becomes elastic - simultaneously demonstrating elements of endurance and flexibility - as members expand and contract their conceptions of who and what the organization is.

\subsection{The 5R Model}

The model below proposes that in times of decline, organization members need to employ one or a combination of five social processes related to organizational identity, referred to as reclaiming, regenerating, reaffirming, retiring, and reimagining (see Figure 1). Each process involves a different set of interpretations about the organization's identity traits.

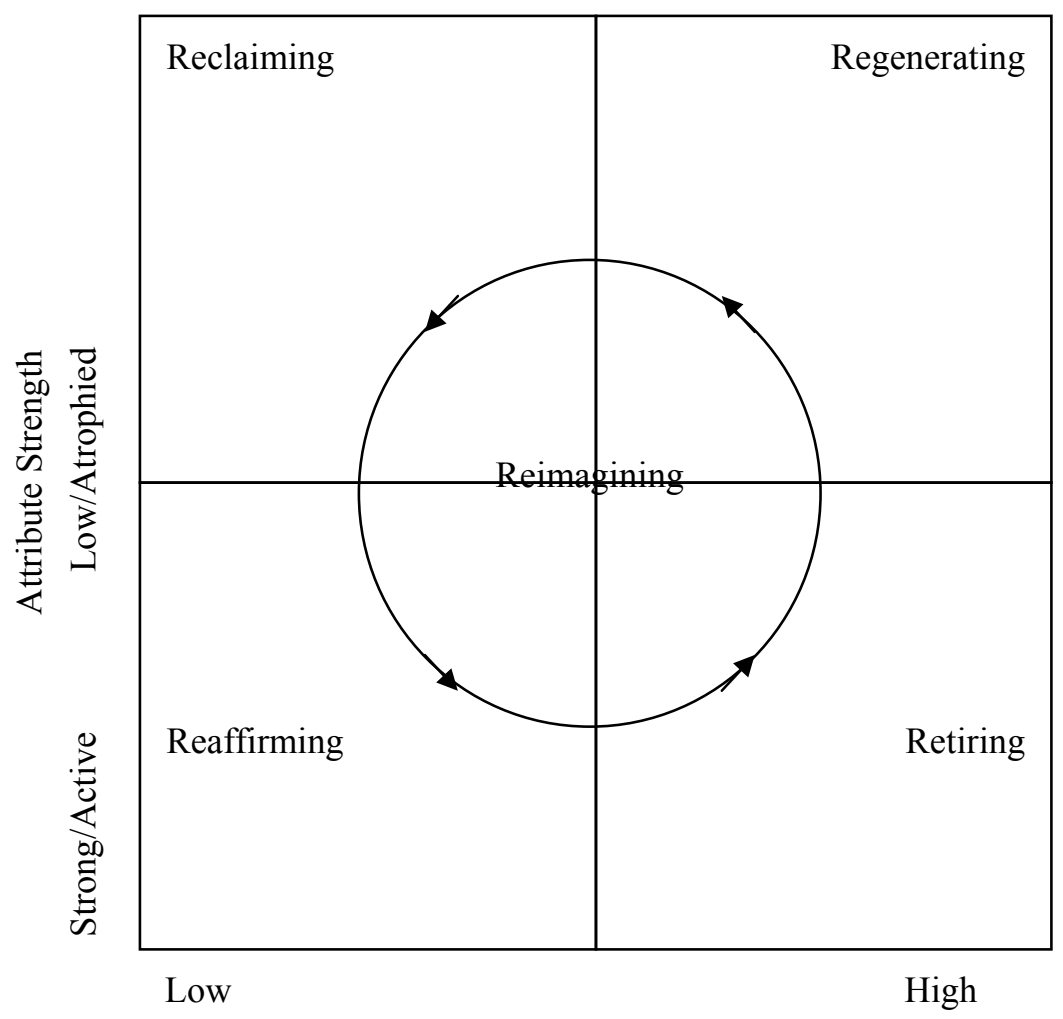

Alignment Effort Needed

Figure 1. The 5R model: Organizational identity processes to avoid organizational decline

In retiring, organizational attributes and identity claims that are active in the organization and within the leaders' and members' organizational consciousness but which hamper or do not support the organization's recovery should be released from the organization's identity and sense of who it is. Effectively retiring core organizational traits can require a great deal of unlearning (Kahneman et al., 1991). For example, Blockbuster's demise in 2010 may have been avoided by retiring its primary focus on brick-and-mortar traditional DVD and video rentals in 
favor of stronger focus on alternative rental models such as streaming on demand videos. A key indicator of its failure to do so is demonstrated in its decision to decline purchasing Netflix in 2000 for a mere $\$ 50$ million (Satell, 2014). Retiring its focus on older business models in favor of cultivating attributes and identity claims consistent with emerging technologies would have supported Blockbuster's competitiveness in a changing market.

In reclaiming, organizational traits that were "lost" in the sense of being forgotten or abandoned by organization members but which still remain intact are recalled, restated, and carried forward in an unchanged manner. For example, in Rockwell's (2013) study of 468 active, licensed ministers' support and identification with core identity attributes of the Foursquare Church revealed only moderate support that "inclusion of ethnicities and diverse cultures" was central, distinctive, and enduring for the organization's identity. Having discovered this, organizational leaders may decide to reclaim this attribute through pastoral education and other efforts to amplify this attribute within its local churches. This quality was strong early in the organization's history and prominent in the behavior of the founder, but had receded in importance in recent decades in the ministers' minds.

In reaffirming, organizational traits that are still within the leaders' and members' organizational consciousness and that still remain relevant for propelling the organization forward and out of the spiral of decline are reasserted and carried forward in an unchanged manner. For example, over 2008 and 2009, Pennsylvania Governor Rendell dramatically cut the budget of Pennsylvania State University and other state-related universities and removed them from the State Fiscal Stabilization Fund, making the bold identity claim that these schools were nonpublic universities because they "were not under the absolute control of the Commonwealth" (Rendell, 2009, p. 14). This represented a clear case of an external stakeholder attempting to retire a core organizational attribute. This externally initiated identity threat triggered substantial identity reconsideration and renegotiation within the organization, culminating in a range of efforts and actions designed to reaffirm the University as a public institution reliant on and deserving of public funding (Ran \& Golden, 2011). State support ultimately was restored in December 2009.

In regenerating, organizational traits that were "lost" in the sense of atrophying or being forgotten or abandoned by organization members, but which remain vital for the organization's future, are restored and recreated. Regenerating can require a substantial amount effort from organizational members to effective accomplish, as it involves determining those attributes needing restoration, directing resources and attention to relabel and reframe those, and creating a wraparound linguistic and visceral experience that supports their recreation. For example, in the case of Pennsylvania State University, a commenter to Stripling's (2009) coverage of the situation voiced that the university had, in fact, strayed from its roots as a Land-Grant university, arguing that the university has focused on attracting increasingly wealthy students in pursuit of prestige and was the most expensive state university in the nation. This individual called for the university to work to create opportunity and success for everyone. Comments like these can act as invitations for organization leaders to return to and bolster neglected identity attributes. It is in regenerating that identity elasticity (Kreiner et al., 2015) may be most evident.

In reimagining, central organizational traits may have atrophied, been forgotten or abandoned, or may remain active in leaders' and members' organizational consciousness. What signifies an organizational trait in need of reimagination is that the trait in a new form is vital for the organization's future. Therefore, organization members may go through a process of reclaiming, retiring, regenerating, and reaffirming certain aspects of the trait, in addition to creating entirely new forms of the trait, as needed. In addition to retiring outdated beliefs and attributes, reimagination is arguably what the Polaroid Corporation needed to compete effectively in a digital imaging market. Tripsas and Gavetti (2000) argued, "For Polaroid, ... success in this new competitive landscape required fundamentally different strategic beliefs" (p. 1159) as well as subsequently different identity claims and behaviors.

\subsection{The Need for Supportive Dialogue and Experiences}

The five social processes of retiring, reclaiming, reaffirming, regenerating, and reimagination requires an integrative effort of sensemaking, sense-giving, and sense-exchanging among leaders and members (Alvesson \& Empson, 2004; Czarniawska-Joerges, 1997; Edwards et al., 2002; Ran \& Golden, 2011; Ravasi \& Schultz, 2006; Scott \& Lane, 2000). In doing so, it is important to create an organizational environment consistent with and supportive of identity claims that support turnaround, so that members' embodied cognition of their organization's identity also reveals a message of turnaround (Harquail \& King, 2010). In this way, organization members' attention and experiences in the organization are managed in a more intentional and positive way to promote self-fulfilling prophecies consistent with success and the specific identity social processes that lead to turnaround. Otherwise, as other researchers have has pointed out, failure is often the path of least resistance for 
organizations in decline (Edwards et al., 2002; McKinley \& Scherer, 2000).

Associated with these activities and central to each of the five processes discussed is what Ybema (2010) calls nostalgic and postalgic narratives, which occur as organization members discursively construct identity and detail how identity narratives are shifting. Ybema elaborated that whereas nostalgic narratives combine discontent about the present with pleasant memories about the past, postalgic narratives disdain the past, idealize the future, and further condemn the intrusion of past ways in the present and future.

Constructing these types of narratives can support the five activities in different ways, as they ignite the self-fulfilling prophecies that powerfully direct organization members' and stakeholders' attention and activities and, in turn, architect the future. For example, nostalgic narratives can be used to rekindle members' excitement about how things used in the past for the purpose of (a) reinstating them in the present and future (for reclaiming activities), (b) highlighting that the organization remains strong in these ways (for reaffirming activities), or (c) emphasizing how cherished identity attributes of the past need to be restored for success in the present and future (for regenerating activities). Postalgic narratives can be useful for supporting the retirement of outdated and deleterious identity attributes.

Reimagining activities likely will require complex combinations of nostalgic and postalgic narratives customized for the various identity attributes organization members want to retire, reclaim, reaffirm, and regenerate. Moreover, although the social processes and associated dialogues need to be deliberate for each social process undertaken, it is particularly critical that the dialogues and experiences are deliberate and robust in cases of identity reimagining. This is necessary because reimagining engages the organization in a complex web of activities of reclaiming forgotten attributes, reaffirming certain active attributes while retiring other ones, and regenerating still others. Additionally, the organization may be building new identity features as a result of internal decline and external changes. Thus, the dialogical process and inner dialogue of the members must be thick and robust.

The failure of New Coke in the mid-1980s may be considered an example of an organization's failure to promote adequate dialogues and processes in the effort to reimagine its identity and associated products. New Coke was first launched in 1985 as a new, sweeter beverage designed to help Coca-Cola compete against Pepsi's growing market share (Greising, 1998). Ultimately, New Coke was on the market only a short time and the public outcry against the new formula was fierce. The original formula was reintroduced less than 3 months later.

Around the same time, another attempt reimagination - this time by Western Union — was successfully achieved. Founded in 1851 by Ezra Cornell, Western Union quickly dominated the telegraph industry. For the next 130 years, the company was a prominent figure in telecommunications. However, as declining profits and mounting debts increasingly plagued the organization, Western Union started divesting itself of telecommunications-based assets and began recasting itself as "the fastest way to send money worldwide" (Western Union Holdings, 2015). Its money transfer revenue exceeded telecommunications revenue for the first time in 1980 and it completely discontinued telegrams in 2006.

\section{Conclusion}

This article proposed a model of identity-related social processes during decline, including retiring, reclaiming, reaffirming, regenerating, and reimagining identity attributes as needed to support organizational turnaround and avoid organizational death. The 5R model could be applied to support organizational turnaround by initiating steps such as defining the organization's ideal identity, diagnosing the organization's current identity and assessing the strength of current identity attributes, define the gap and needed change actions, and planning and executing appropriate change processes. Enacting such activities could help begin to test the implications and limitations of the model. It is important to note that although this model is rooted in past studies and literature on organizational decline and organizational identity, empirical research is needed to validate or adjust the model. Future work could involve examination of identity negotiations within past cases of organizational decline and turnaround as well as devising and testing specific retiring, reclaiming, reaffirming, regenerating, and reimagining interventions.

\section{References}

Acedo, F. J., Barroso, C., \& Galan, J. L. (2006). The resource-based theory: Dissemination and main trends. Strategic Management Journal, 27(7), 621-636. http://dx.doi.org/10.1002/smj.532

Adizes, I. (1979). Organizational passages: Diagnosing and treating life cycle problems in organizations. $\begin{array}{lllll}\text { Organizational Dynamics, } & 8, & 3-24 & \text { Retrieved } & \text { from }\end{array}$ http://www.journals.elsevier.com/organizational-dynamics/ 
Aldrich, H. E., \& Auster, E. (1986). Even dwarfs started small: Liabilities of size and age and their strategic implications. Research in Organizational Behavior, 8, 165-198. Retrieved from $\mathrm{http}: / / \mathrm{www}$.journals.elsevier.com/research-in-organizational-behavior/

Alvesson, M., \& Empson, L. (2004). The construction of organizational identity: Comparative case studies of consulting firms. Lund Institute of Economics Working Paper Series. Retrieved from http://www.lri.lu.se/pdf/wp/2006-3.pdf

Argenti, J. (1976). Corporate collapse: The causes and symptoms. New York, NY: McGraw-Hill.

Arthur, W. B. (1994). Increasing returns and path dependence in the economy. Ann Arbor, MI: University of Michigan Press.

Ashforth, B. E., \& Mael, F. (1989). Social identity theory and the organization. Academy of Management Review, 14(1), 20-39. http://dx.doi.org/10.5465/AMR.1989.4278999

Audia, P., \& Greve, H. (2006). Less likely to fail: Low performance, firm size, and factory expansion in the shipbuilding industry. Management Science, 52, 83-94. http://dx.doi.org/10.1287/mnsc. 1050.0446

Barnard, C. (1938). The functions of the executive. Cambridge, MA: Harvard University Press.

Barnett, W. P., \& Pontikes, E. G. (2008). The red queen, success bias, and organizational inertia. Management Science, 54(7), 1237-1251. http://dx.doi.org/10.1287/mnsc.1070.0808

Barney, J. B. (2001). Is the resource-based 'view' a useful perspective for strategic management research? Yes. Academy of Management Review, 26(1), 41-56. http://dx.doi.org/10.5465/AMR.2001.4011938

Baum, J., \& Shipilov, A. (2006). Ecological approaches to organizations. In S. Clegg, C. Hardy, T. Laurence, \& W. North (Eds.), Handbook for organization studies (pp. 55-66). London, UK: Sage.

Becker, M. C. (Ed.). (2008). Handbook of organizational routines. Cheltenham, UK: Edward Elgar.

Bedeian, A. (1980). Organizations: Theory and analysis. Hinsdale, IL: Dryden.

Berger, P. L., \& Luckmann, T. (1966). The social construction of reality: A treatise in the sociology of knowledge. New York, NY: Doubleday.

Bowen, M. G. (1987). The escalation phenomenon reconsidered: decision dilemmas or decision errors? Academy of Management Review, 12(1), 52-66. http://dx.doi.org/10.5465/AMR.1987.4306470

Brockner, J. (1992). The escalation of commitment to a failing course of action: Toward theoretical progress. Academy of Management Review, 17(1), 39-61. http://dx.doi.org/10.5465/AMR.1992.4279568

Brown, A. D., \& Starkey, K. (2000). Organizational identity and learning: A psychodynamic perspective. Academy of Management Review, 25(1), 102-120. http://dx.doi.org/10.5465/AMR.2000.2791605

Cameron, K. S., Kim, M. U., \& Whetten, D. A. (1987). Organizational effects of decline and turbulence. Administrative Science Quarterly, 32, 222-240. http://dx.doi.org/10.2307/2393127

Carmeli, A., \& Schaubroeck, J. (2006). Top management team behavioral integration, decision quality, and $\begin{array}{lllll}\text { organizational } \quad \text { decline. } & \text { Leadership }\end{array}$ http://dx.doi.org/10.1016/j.leaqua.2006.06.001

Chreim, S. (2005). The continuity-change duality in narrative texts of organizational identity. Journal of Management Studies, 42(3), 567-593. http://dx.doi.org/10.1111/j.1467-6486.2005.00509.x

Conner, K. R. (1991). Historical comparison of resource-based theory and 5 schools of thought within industrial organization economics. Journal of Management, 17(1), 121-154. Retrieved from http://jom.sagepub.com/

Corley, K. G., Harquail, C. V., Pratt, M. G., Glynn, M. A., Fiol, C. M., \& Hatch, M. J. (2006). Guiding organizational identity through aged adolescence. Journal of Management Inquiry, 15(2), 85-99. http://dx.doi.org/10.1177/1056492605285930

Cornelissen, J. P. (2006). Making sense of theory construction: Metaphor and disciplined imagination. Organization Studies, 27(11), 1579-1597. http://dx.doi.org/10.1177/0170840606068333

Czarniawska, B. (1994). Narratives of individual and organizational identities. In S. A. Deetz (Ed.), Communication yearbook (Vol. 17, pp. 193-221). London, UK: Sage.

Czarniawska-Joerges, B. (1997). Narrating the organization: Dramas of institutional identity. Chicago: University of Chicago Press. 
Donaldson, L. (2001). The contingency theory of organizations. Thousand Oaks, CA: Sage.

Dutton, J. E., \& Dukerich, J. M. (1991). Keeping an eye on the mirror: Image and identity in organizational adaption. Academy of Management Journal, 31, 517-554. http://dx.doi.org/10.2307/256405

Dutton, J. E., Dukerich, J. M., \& Harquail, C. V. (1994). Organizational images and member identification. Administrative Science Quarterly, 39, 239-262. http://dx.doi.org/10.2307/2393235

Edwards, J. C., McKinley, W., \& Moon, G. (2002). The enactment of organizational decline: The self-fulfilling prophecy. International Journal of Organizational Analysis, 10(1), 55-75. http://dx.doi.org/10.1108/eb028944

Elstak, M. N. (2008). The paradox of the organizational identity field. Corporate Reputation Review, 11, 277-281. http://dx.doi.org/10.1057/crr.2008.22

Ford, J. (1980). The occurrence of structural hysteresis in declining organizations. Academy of Management Review, 5, 589-598. http://dx.doi.org/10.5465/AMR.1980.4288964

Freeman, J., \& Hannan, M. (1983). Niche width and the dynamics of organizational populations. American Journal of Sociology, 88, 1116-1145. http://dx.doi.org/10.1086/227797

Freeman, S. J., \& Cameron, K. S. (1993). Organizational downsizing: A convergence and reorientation framework. Organization Science, 4, 10-29. http://dx.doi.org/10.1287/orsc.4.1.10

Gavetti, G., \& Levinthal, D. (2000). Looking forward and looking backward: Cognitive and experimental search. Administrative Science Quarterly, 45(1), 113-137. http://dx.doi.org/10.2307/2666981

Gioia, D. A., \& Thomas, J. B. (1996). Identity, image, and issue interpretation: Sensemaking during strategic change in academia. Administrative Science Quarterly, 41(3), 370-403. http://dx.doi.org/10.2307/2393936

Gioia, D. A., Schultz, M., \& Corley, K. G. (2000). Organizational identity, image, and adaptive instability. Academy of Management Review, 25(1), 63-81. http://dx.doi.org/10.5465/AMR.2000.2791603

Greising, D. (1998). I'd like the world to buy a Coke: The life and leadership of Roberto Goizueta. New York, NY: Wiley.

Hambrick, D., \& D'Aveni, R. (1988). Large corporate failures as downward spirals. Administrative Science Quarterly, 33, 1-23. http://dx.doi.org/10.2307/2392853

Hannan, M. T., \& Carroll, G. R. (1992). Dynamics of organizational populations: Density, competition, and legitimation. New York, NY: Oxford University Press.

Hannan, M. T., \& Freeman, J. (1984). Structural inertia and organizational change. American Sociological Review, 49, 149-164. http://dx.doi.org/10.2307/2095567

Harquail, C. V., \& King, A. W. (2010). Construing organizational identity: The role of embodied cognition. Organization Studies, 31(12), 1619-1648. http://dx.doi.org/10.1177/0170840610376143

Harrison, J. D. (2000). Multiple imaginings of institutional identity: A case study of a large psychiatric research hospital. Journal of Applied Behavioral Science, 36, 425-455. http://dx.doi.org/10.1177/0021886300364003

Hatch, M. J., \& Schultz, M. (2008). Taking brand initiative: How companies can align strategy, culture, and identity through corporate branding. San Francisco, CA: Jossey-Bass.

Hayward, M. L. A., \& Shimizu, K. (2006). De-commitment to losing strategic action: Evidence from the divestiture of poorly performing acquisitions. Strategic Management Journal, 27(6), 541-557. http://dx.doi.org/10.1002/smj.526

Heine, K., \& Rindfleisch, H. (2013). Organizational decline. Journal of Organizational Change Management, 26(1), 8-28. http://dx.doi.org/10.1108/09534811311307888

Heracleous, L., \& Jacobs, C. D. (2008). Understanding organizations through embodied metaphors. Organization Studies, 29(1), 45-78. http://dx.doi.org/10.1177/0170840607086637

Hodgkinson, G. P., \& Wright, G. (2002). Confronting strategic inertia in a top management team: Learning from failure. Organization Studies, 23(6), 949-977. http://dx.doi.org/10.1177/0170840602236014

Hoy, F. (2006, November). The complicating factor of life cycles in corporate venturing. Entrepreneurship: Theory \& Practice, 831-836. http://dx.doi.org/10.1111/j.1540-6520.2006.00154.x 
Humphreys, M., \& Brown, A. D. (2002). Narratives of organizational identity and identification: A case study of $\begin{array}{lllll}\text { hegemony and } & \text { resistance. }\end{array}$ http://dx.doi.org/10.1177/0170840602233005

Johnson, V. (2007). What is organizational imprinting? Cultural entrepreneurship in the founding of the Paris opera. American Journal of Sociology, 113(1), 97-127. http://dx.doi.org/10.1086/517899

Kahneman, D., Knetsch, J. L., \& Thaler, R. H. (1991). Anomalies: The endowment effect, loss aversion, and status quo bias. Journal of Economic Perspectives, 5(1), 193-206. http://dx.doi.org/10.1257/jep.5.1.193

Kimberly, J. R., \& Miles, R. H. (1980). The organizational life cycle: Issues in the creation, transformation, and decline of organizations. San Francisco, CA: Jossey-Bass.

Kraaijenbrink, J., Spender, J. C., \& Groen, A. J. (2010). The resource-based view: A review and assessment of its critiques. Journal of Management, 36(1), 349-372. http://dx.doi.org/10.1177/0149206309350775

Kreiner, G. E., Hollensbe, E., Sheep, M. L., Smith, B. R., \& Kataria, N. (2015). Elasticity and the dialectic tensions of organizational identity: How can we hold together while we are pulling apart? Academy of Management Journal, 58(4), 981-1011. http://dx.doi.org/10.5465/amj.2012.0462

Lumpkin, G. T., \& Dess, G. G. (2006). The effect of 'simplicity' on the strategy-performance relationship: A $\begin{array}{lllll}\text { note. Journal of } & \text { Management }\end{array}$ http://dx.doi.org/10.1111/j.1467-6486.2006.00652.x

Martin, D. D. (2002). From appearance tales to oppression tales: Frame alignment and organizational identity. Journal of Contemporary Ethnography, 31(1), 158-206. http://dx.doi.org/10.1177/0891241602031002003

Masuch, M. (1985). Vicious circles in organizations. Administrative Science Quarterly, 30, 14-23. http://dx.doi.org/10.2307/2392809

McKinley, W. (1987). Complexity and administrative intensity: The case of declining organizations. Administrative Science Quarterly, 32, 87-105. http://dx.doi.org/10.2307/2392744

McKinley, W. (1993). Organizational decline and adaptation: Theoretical controversies. Organization Science, 4, 1-9. http://dx.doi.org/10.1287/orsc.4.1.1

McKinley, W., \& Scherer, A. G. (2000). Some unanticipated consequences of organizational restructuring. Academy of Management Review, 25, 735-752. http://dx.doi.org/10.5465/AMR.2000.3707703

McKinley, W., Latham, S., \& Braun, M. (2014). Organizational decline and innovation: Turnarounds and downward spirals. Academy of Management Review, 39(1), 88-110. http://dx.doi.org/10.5465/AMR.2011.0356

Meyer, A. D. (1982). Adapting to environmental jolts. Administrative Science Quarterly, 27, 515-537. http://dx.doi.org/10.2307/2392528

Miller, D. (1990). The Icarus paradox: How exceptional companies bring about their own downfall. New York, NY: HarperCollins.

Miller, D. (1993). The architecture of simplicity. Academy of Management Review, 18(1), 116-138. http://dx.doi.org/10.5465/AMR.1993.3997509

Miller, D., \& Friesen, P. (1984). A longitudinal study of the corporate life cycle. Management Science, 30(10), 1161-1183. http://dx.doi.org/10.1287/mnsc.30.10.1161

Pandit, N. (2000). Some recommendations for improved research on corporate turnaround. Management, 3(2), 31-56. Retrieved from http://www.management-aims.com/fichiers/publications/32Pandit.pdf

Pearson, C. M., \& Clair, J. A. (1998). Reframing crisis management. Academy of Management Review, 23, 59-76. http://dx.doi.org/10.5465/AMR.1998.192960

Penrose, E. (1959). The theory of the growth of the firm. New York, NY: Oxford University Press.

Pfeffer, J., \& Salancik, G. (1978). The external control of organizations: A resource dependence perspective. New York, NY: Harper \& Row.

Pierson, P. (2000). Increasing returns, path dependence, and the study of politics. American Political Science Review, 94(2), 251-267. http://dx.doi.org/10.2307/2586011

Porter, M. (1980). Competitive strategy: Techniques for analyzing industries and competitors. New York, NY: Free Press. 
Pratt, M. G., \& Foreman, P. O. (2000). Classifying managerial responses to multiple organizational identities. Academy of Management Review, 25(1), 18-42. http://dx.doi.org/10.5465/AMR.2000.2791601

Quinn, R., \& Cameron, K. (1983). Organizational life cycles and shifting criteria of effectiveness: Some preliminary evidence. Management Science, 29(1), 33-51. http://dx.doi.org/10.1287/mnsc.29.1.33

Ran, B., \& Duimering, P. R. (2007). Imaging the organization: Language use in organizational identity claims. Journal of Business and Technical Communication, 21, 155-187. http://dx.doi.org/10.1177/1050651906297167

Ran, B., \& Golden, T. J. (2011). Who are we? The social construction of organizational identity through sense-exchanging. Administration \& Society, 43(4), 417-445. http://dx.doi.org/10.1177/0095399711412727

Ranft, A. L., \& O'Neill, H. M. (2001). Board composition and high-flying founders: Hints of trouble to come? Academy of Management Executive, 15(1), 126-138. http://dx.doi.org/10.5465/AME.2001.4251562

Ravasi, D., \& Schultz, M. (2006). Responding to organizational identity threats: Exploring the role of organizational culture. Academy of Management Journal, 49, 433-458. http://dx.doi.org/10.5465/AMJ.2006.21794663

Rendell, E. (2009, June 26). Pennsylvania State Fiscal Stabilization Funds Application. Retrieved from http://www.state.pa.us/portal/server.pt/gateway/PTARGS_0_2_60658_0_0_43/http\%3B/pubcontent.state.p a.us/publishedcontent/publish/marketingsites/recovery_pa_gov/content/announcements/announcements_list /pa_sfsf_application_2009_06_26.pdf

Robbins, D. K., \& Pearce, J. A. II. (1992). Turnaround: Retrenchment and recovery. Strategic Management Journal, 13, 287-309. http://dx.doi.org/10.1002/smj.4250130404

Rockwell, S. (2013). Denominational identity and ministerial identity congruence within the Foursquare Church (Doctoral dissertation). ProQuest Dissertations and Theses database. (UMI No. 3554081)

Satell, G. (2014, September 5). A look back at why Blockbuster really failed and why it didn't have to. Forbes. Retrieved from http://www.forbes.com/sites/gregsatell/2014/09/05/a-look-back-at-why-blockbuster-really-failed-and-why-i t-didnt-have-to/

Schultz, M., Maguire, S., Langley, A., \& Tsoukas, H. (2012). Constructing identity in and around organizations. Oxford, UK: Oxford University Press.

Scott, B. (1971). Stages of corporate development-Part I. Cambridge, MA: Intercollegiate Case Clearing House, Harvard University.

Scott, S. G., \& Lane, V. R. (2000). A stakeholder approach to organizational identity. Academy of Management Journal, 25, 43-62. http://dx.doi.org/10.5465/AMR.2000.2791602

Scott, W. R. (2003). Organizations: Rational, natural, and open systems. Upper Saddle River, NJ: Prentice Hall.

Serra, F. R., Ferreira, M. P., \& Ribeiro de Almeida, M. I. (2013). Organizational decline: A yet largely neglected topic in organizational studies. Management Research, 11(2), 133-156. http://dx.doi.org/10.1108/MRJIAM-Mar-2012-0476

Sheep, M. L., \& Hollensbe, E. C. (2009). Tearing fabric or weaving tapestry? Discursive interplay of culture and organizational identities. Paper presented at the Academy of Management Meetings, Chicago, August 2009.

Sheppard, J. P. (1994). Strategy and bankruptcy: An exploration into organizational death. Journal of Management, 20(4), 795-883. http://dx.doi.org/10.1016/0149-2063(94)90031-0

Shimizu, K., \& Hitt, M. A. (2005). What constraints or facilitates divestitures of formerly acquired firms? The effects of organizational inertia. Journal of Management, 31, 50-72. http://dx.doi.org/10.1177/0149206304271381

Starbuck, W. H., Greve, A., \& Hedberg, B. L. T. (1978). Responding to crises. Journal of Business Administration, 9(2), 111-137. Retrieved from https://www.atu.edu/jbao/

Staw, B. M., Sandelands, L. E., \& Dutton, J. E. (1981). Threat rigidity effects in organizational behavior: A multilevel analysis. Administrative Science Quarterly, 26, 501-524. http://dx.doi.org/10.2307/2392337

Stieglitz, N., \& Heine, K. (2007). Innovations and the role of complementarities in a strategic theory of the firm. Strategic Management Journal, 28(1), 1-15. http://dx.doi.org/10.1002/smj.565 
Stripling, J. (2009). Go ask Arne. Inside Higher Education. Retrieved from http://www.insidehighered.com/news/2009/07/02/penn

Suchman, M. C. (1995). Managing legitimacy: Strategic and institutional approaches. Academy of Management Journal, 20, 571-610. http://dx.doi.org/10.5465/AMR.1995.9508080331

Sveningsson, S., \& Alvesson, M. (2003). Managing managerial identities: Organizational fragmentation, discourse and identity struggle. Human Relations, 56(10), 1161-1193. http://dx.doi.org/10.1177/00187267035610001

Torres, A., Serra, F., Ferreira, M., \& Menezes, E. (2011). The decline of large Brazilian companies. Corporate Ownership and Control, 8(4), 214-224. Retrieved from http://spell.org.br/documentos/ver/13022/o-declinio-de-uma-empresa-brasileira-de-grande-porte--o-caso-gr adiente/i/pt-br

Tripsas, M., \& Gavetti, G. (2000). Capabilities, cognition, and inertia: Evidence from digital imaging. Strategic Management Journal: Special Issue: The Evolution of Firm Capabilities, 21(10/11), 1147-1161. http://dx.doi.org/10.1002/1097-0266(200010/11)21:10/11\%3C1147::AID-SMJ128\%3E3.0.CO;2-R

Tushman, M., \& Anderson, P. (1986). Technological discontinuities and organizational environments. Administrative Science Quarterly, 31, 439-465. http://dx.doi.org/10.2307/2392832

Tversky, A., \& Kahneman, D. (1981). The framing of decisions and the psychology of choice. Science, 211(4481), 453-458. http://dx.doi.org/10.1126/science.7455683

Van Rekom, J., Corley, K. G., \& Ravasi, D. (2008). Extending and advancing theories of organizational identity. Corporate Reputation Review, 11, 183-188. http://dx.doi.org/10.1057/crr.2008.21

Venkataraman, S., \& Low, M. (1994). The effects of liabilities of age and size on autonomous sub-units of established firms in the steel industry. Journal of Business Venturing, 9(3), 189-204. http://dx.doi.org/10.1016/0883-9026(94)90029-9

Weitzel, W., \& Jonsson, E. (1989). Decline in organizations: A literature integration and extension. Administrative Science Quarterly, 34, 91-109. http://dx.doi.org/10.2307/2392987

Wernerfelt, B. (1984). The resource-based view of the firm. Strategic Management Journal, 5(2), 171-180. http://dx.doi.org/10.1002/smj.4250050207

Western Union Holdings. (2015). Our rich history. Retrieved from http://corporate.westernunion.com/History.html

Whetten, D. A. (1980a). Organizational decline: A neglected topic in organizational science. Academy of Management Review, 5, 577-588. http://dx.doi.org/10.5465/AMR.1980.4288962

Whetten, D. A. (1980b). Sources, responses, and effects of organizational decline. In J. R. Kimberly, R. H. Miles, \& Associates (Eds.), The organizational life cycle (pp. 342-374). San Francisco, CA: Jossey-Bass.

Whetten, D. A. (2006). Albert and Whetten revisited: Strengthening the concept of organizational identity. Journal of Management Inquiry, 15, 219-234. http://dx.doi.org/10.1177/1056492606291200

Whetten, D. A., \& Godfrey, P. C. (1998). Identity in organizations: Building theory through conversations. Thousand Oaks, CA: Sage.

Whetten, D. A., \& Mackey, A. (2002). A social actor conception of organizational identity and its implications for the study of organizational reputation. Business and Society, 41(4), 393-414. http://dx.doi.org/10.1177/0007650302238775

Ybema, S. (2010). Talk of change: Temporal contrasts and collective identities. Organization Studies, 31(4), 481-503. http://dx.doi.org/10.1177/0170840610372205

\section{Copyrights}

Copyright for this article is retained by the author(s), with first publication rights granted to the journal.

This is an open-access article distributed under the terms and conditions of the Creative Commons Attribution license (http://creativecommons.org/licenses/by/3.0/). 